\title{
Leaf Epidermal Micromorphology of Portulaca L. Species Found in Vadodara, Gujarat, India
}

\author{
Archana Srivastava, Aruna Girish Joshi, and Vinay Madhukar Raole \\ Department of Botany, Faculty of Science, The Maharaja Sayajirao University of Baroda, Vadodara 390002, India \\ Correspondence should be addressed to Aruna Girish Joshi; arunajoshimsu@gmail.com
}

Received 8 July 2013; Revised 2 September 2013; Accepted 22 September 2013

Academic Editor: Philip J. White

Copyright ( 2013 Archana Srivastava et al. This is an open access article distributed under the Creative Commons Attribution License, which permits unrestricted use, distribution, and reproduction in any medium, provided the original work is properly cited.

Micromorphology of three species of Portulaca was carried out with the help of light microscopy to determine variations within the species which would aid in correct identification of the plants. Epidermal cells are polygonal with sinuous anticlinal walls in all the three species. Length of epidermal cells of P. grandiflora Hook. is higher than P. oleracea Linn. and P. quadrifida Linn. The leaves of $P$. quadrifida are epistomatic while the remaining species are amphistomatic with paracytic stomata in all the three species. Mean stomatal index and stomatal frequency are more in P. quadrifida while the mean size of stomata (both length and width) is larger in P. grandiflora for both adaxial and abaxial surfaces. Based on the diagnostic features, an artificial indented key is prepared.

\section{Introduction}

The members of the family Portulacaceae are cosmopolitan generally herbs and shrubs with 15-30 genera and 500 species [1]. According to Geesink [2], Portulaca Linn is divided into two subgenera: subgenera Portulacella (F. Muell.) Legrand with glabrous nodes and flowers in dichasia and subgenera Portulaca with nodal scales or hairs and terminal flowers. The presently studied species belong to subgenera Portulaca. All the three species are recorded from the west of North America, South America, and Africa with some representatives in Europe and Asia [3]. The plants are native to the tropics of the western hemisphere [4].

The species selected for the present study are P. grandiflora, $P$. oleracea, and P. quadrifida which are suggested in medicine. P. grandiflora is a succulent, prostrate, ascending, pretty herb with subblooming flowers [5], used for the relief of sore throat, skin rashes, and detoxification [6]. P. quadrifida is small succulent with elliptic to ovate leaves. Flowers are yellow, solitary, terminal with conical capsule and minutely tubercle seeds [5]. It is used for various curative purposes such as asthma, cough, urinary discharge, inflammation, ulcers, abdominal complaints, erysipelas, and hemorrhoids $[7,8]$. P. oleracea is a succulent, erect herb with oblong ovate or spathulate leaves and cuneate or sessile base. Flowers are yellow with terminal or axillary clusters. Capsule is ovoid with black muriculate seeds. It is antibacterial, -virus, -antherosis, -caducity and enhances immunity. It is also useful in headache, stomachache, painful urination, dysentery, enteritis, astitis, lack of milk flow in nursing mothers, and in postpartum bleeding, inflammation, skin sores, and ulcers. Fresh herb is used as poultice or juice $[9,10]$ and in unani formulation "Qur Tabasheer" useful as antihyperglycemic and antihyperlipidemic drug [11].

Micromorphological studies are already known to be useful in elucidating the characters in the vegetative phase. Within the members of Caryophyllales, various aspects of micromorphology have been studied, for example, seed coat micromorphology of Aizoaceae, Gisekiaceae [12], Molluginaceae [13], Caryophyllaceae [14], and epicuticular waxes of Amaranthaceae members such as Arthraerua [15], Gomphrena [16], and Centrosperms [17]. Seed, pollen grains, and leaf micromorphology of Saponaria (Caryophyllaceae) [18] and members of Amaranthaceae such as Gomphrena [19] and Achyranthes [20] have been studied in detail. Heywood [21] reports that genera's of Portulacaceae are ill-defined and they can very well be distinguished from one another by microscopic features, which are of prime assistance in demarcation at the species level. Kadiri [22] suggests that there is insufficient information on the microscopic characters of 
TABle 1: Characteristics of stomata of Portulaca spp. (Mean \pm S.E) $\left({ }^{*} \mu \mathrm{m},{ }^{* *}\right.$ per $\left.\mathrm{mm}^{2},{ }^{* * *} \%\right)$.

\begin{tabular}{|c|c|c|c|c|}
\hline Stomatal characters & & P. grandiflora & P. oleracea & P. quadrifida \\
\hline \multirow{2}{*}{ Type } & Adaxial & Paracytic & Paracytic & Paracytic \\
\hline & Abaxial & Paracytic & Paracytic & - \\
\hline \multirow{2}{*}{ Length* } & Adaxial & $4.01 \pm 0.12$ & $3.88 \pm 0.20$ & $2.52 \pm 0.18$ \\
\hline & Abaxial & $4.76 \pm 0.22$ & $4.26 \pm 0.11$ & - \\
\hline \multirow{2}{*}{ Width $^{*}$} & Adaxial & $3.45 \pm 0.18$ & $2.95 \pm 0.15$ & $2.10 \pm 0.23$ \\
\hline & Abaxial & $4.06 \pm 0.32$ & $3.80 \pm 0.25$ & - \\
\hline \multirow{2}{*}{ Frequency $^{* *}$} & Adaxial & $13.34 \pm 0.62$ & $13.25 \pm 0.90$ & $54.60 \pm 1.06$ \\
\hline & Abaxial & $20.95 \pm 0.86$ & $14.00 \pm 0.38$ & - \\
\hline \multirow{2}{*}{ Index ${ }^{* * *}$} & Adaxial & $22.07 \pm 0.45$ & $18.35 \pm 0.60$ & $35.55 \pm 0.86$ \\
\hline & Abaxial & $23.34 \pm 0.41$ & $18.03 \pm 0.44$ & - \\
\hline
\end{tabular}

the members of the family Portulacaceae which can aid in their easy recognition and confirmation. His study reports that the species of Portulaca from Nigeria are amphistomatic but in India $P$. quadrifida is found to be epistomatic. This led us to enquire whether geographical regions are causing substantial variations within the species. It would also be helpful in understanding the taxonomical and phylogenetic relationship within the genera. Micromorphology study of these species will give an insight in identifying different species with characters like epidermal cells and stomata to prepare a good dataset to reduce the adulteration in the medicinal formulations.

\section{Materials and Methods}

All the three species were collected from the Faculty of Science campus, The M. S. University of Baroda, Vadodara, and were deposited in the departmental herbaria with voucher specimen number being P. grandiflora $=274$, . oleracea $=275$, and $P$. quadrifida $=276$. For $P$. grandiflora and $P$. oleracea, epidermal peels from the leaves were obtained by peel method, washed in water, stained in safranin, and mounted with $50 \%$ glycerine. P. quadrifida has minute leaves and so it was macerated with Jaffrey's solution. Fifteen observations each covering the entire leaves were done for all the three species and each slide was observed for 15 microscopic fields for both the surfaces. The epidermal characters of the cell, stomata, and trichome were studied. Quantitative features such as length of the epidermal cell, size of stomata, stomatal index, and stomatal frequency have been determined as follows:

$$
\mathrm{SI}=\left(\frac{S \times 100}{E+S}\right)
$$

where SI is the stomatal index percent, $S$ is the number of stomata/field of study, and $E$ is the number of epidermal cells/field of study.

\section{Stomatal Frequency}

$=$ Number of stomata per unit leaf area.
All observations and photomicrographs were obtained with Leica research microscope.

\section{Results}

For the present work, descriptive terminologies described by Metcalfe and Chalk [23] have been followed. The leaves of $P$. grandiflora and $P$. oleracea are amphistomatic while those of P. quadrifida are epistomatic. The stomatal type was paracytic on both the adaxial and abaxial surfaces of $P$. grandiflora and P. oleracea, and in P. quadrifida it is paracytic on the adaxial surface and absent on abaxial surface (Figure 1). The stomata were oriented at a right angle to the midrib of the leaf in case of $P$. grandiflora and $P$. quadrifida but in $P$. oleracea it was irregularly scattered. The length and width of stomata is more on abaxial surface than adaxial surface for $P$. grandiflora and P. oleracea (Table 1). For both the adaxial and abaxial surfaces, the length of stomata are more in $P$. grandiflora followed by $P$. oleracea and $P$. quadrifida (Table 1). Similar pattern is depicted in width of stomata for both of the surfaces. Stomatal frequency per $\mathrm{mm}^{2}$ on the adaxial surface is higher in $P$. quadrifida (54.60) while it is similar in $P$. grandiflora and $P$. oleracea. On the abaxial surface, the stomatal frequency per $\mathrm{mm}^{2}$ is more in P. grandiflora than P. oleracea. Mean stomatal index percent on the adaxial surface is again higher in $P$. quadrifida (35.55\%) followed by P. grandiflora and P. oleracea, while on the abaxial surface $P$. grandiflora has a high mean stomatal index percent (Table 1).

Micromorphological features of $P$. grandiflora and $P$. oleracea revealed that both the abaxial and adaxial surfaces have ordinary epidermal cells with polygonal sinuous anticlinal walls (Figures 1(a), 1(b), 1(c), and 1(d)). In P. quadrifida, on the adaxial surface, the cells are polygonal while the cells on abaxial surface are almost isodiametric (Figures 1(e) and 1(f)). The mean length of epidermal cells in all the three species does not show much variation with their respective adaxial and abaxial surfaces. On the adaxial surface, the mean length of epidermal cells is higher in $P$. grandiflora and similar in $P$. oleracea and P. quadrifida (Table 2). On the abaxial surface the mean length of ordinary epidermal cells is higher in $P$. grandiflora than in P. oleracea and P. quadrifida (Table 2). Besides this, P. grandiflora and P. oleracea were found to be 


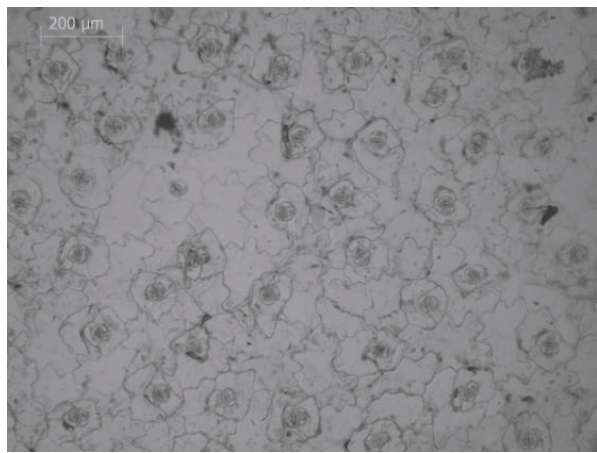

(a)

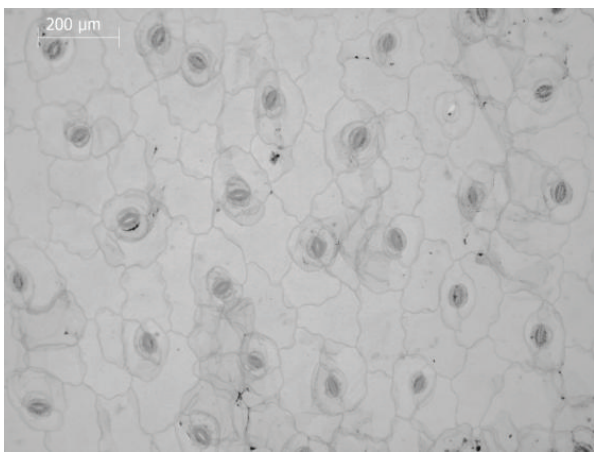

(c)

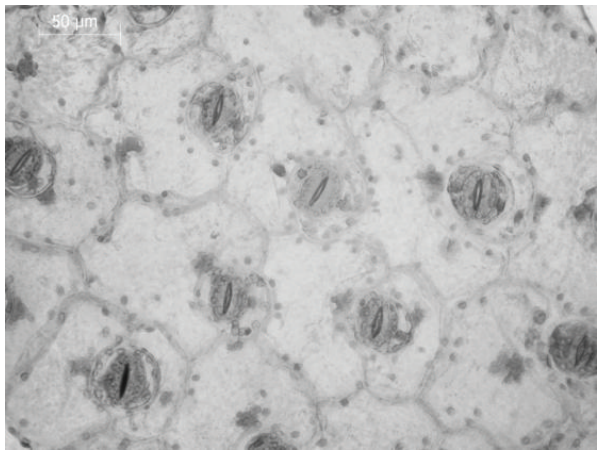

(e)

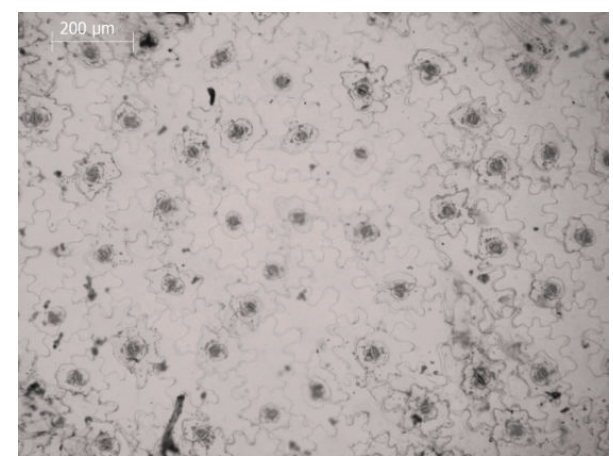

(b)

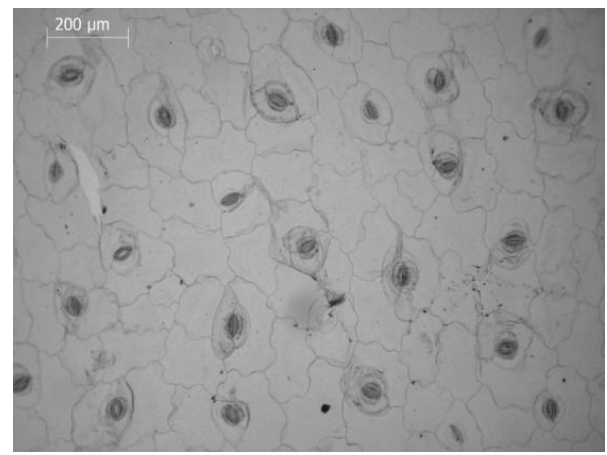

(d)

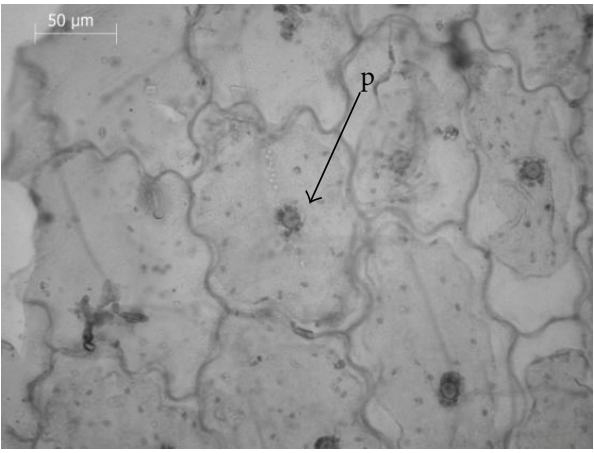

(f)

FIGURE 1: Foliar epidermal peels of: (a) and (b) adaxial and abaxial surface of $P$. grandiflora with sinuous anticlinal epidermal cell walls and paracytic stomata, (c) and (d) adaxial and abaxial surface of P. oleracea with undulating anticlinal epidermal cell walls and paracytic stomata, (e) adaxial surface of $P$. quadrifida with undulating anticlinal epidermal cell walls and paracytic stomata, and (f) abaxial surface of $P$. quadrifida with no stomata showing papillae (p).

glabrous while $P$. quadrifida was pubescent having papillae trichome.

\section{Discussion}

The present study elucidates the micromorphological features of three species of Portulaca, namely, P. grandiflora, P. oleracea, and P. quadrifida. Portulaca species of Nigeria has been studied by Kadiri [22], however its Indian counterpart shows micromorphological variations. Kadiri has reported that the three species are amphistomatic and the epidermal cells of $P$. grandiflora on the adaxial surface are to be isodiametric but the present investigation revealed that $P$. grandiflora has polygonal cells while $P$. quadrifida is epistomatic with its epidermal cells on the abaxial surface to be isodiametric. Besides this, the size of stomata is larger in the Nigerian species as compared to its Indian counterpart. Observations which were similar to Kadiri [22] are the presence of paracytic stomata, larger and higher number of stomata on abaxial surface in all the three species, and uniformity of stomatal distribution in $P$. oleracea. The stomata are paracytic type, flanked on either side by unequal girdling epidermal cells in all the three species. The subsidiary cells are surrounded by an additional tier of cell where the inner wall forms an arc around the subsidiary cells while the outer wall is sinuous like an ordinary epidermal cell. Similar epidermal 
TABle 2: Characteristics of leaf epidermis of Portulaca spp. (Mean \pm S.E) $\left({ }^{*} \mu \mathrm{m}\right)$.

\begin{tabular}{llccc}
\hline Traits & & P. grandiflora & P. oleracea & P. quadrifida \\
\hline \multirow{2}{*}{ Length of epidermal cell ${ }^{*}$} & Adaxial & $22.12 \pm 1.36$ & $12.95 \pm 0.44$ & $12.53 \pm 0.60$ \\
& Abaxial & $23.94 \pm 0.97$ & $15.89 \pm 0.81$ & $13.30 \pm 0.45$ \\
\multirow{2}{*}{ Pattern of anticlinal wall } & Adaxial & Sinuous & Sinuous & Sinuous \\
& Abaxial & Sinuous & Sinuous & Sinuous \\
\hline
\end{tabular}

cell pattern is also reported in Calandrinia and Montopsis of family Portulacaceae [24] and in Cinnamomum schaeffer [25]. In this study, the stomata were paracytic type which is also reported in Cistanthe [26] and Talinum of Portulacaceae [27]. There is not much difference between adaxial and abaxial surfaces for the parameters such as stomatal index which is also reflected in the study of Cistanthe [26].

Significant observations were made in P. quadrifida where the stomata were found to be oriented at right angle to the midrib of the leaf which is in agreement with the studies of Rajagopal [28]. The leaves were found to be epistomatic in nature, and Salisbury [29], Weaver and Clements [30] have noted that the frequency as well as surface distribution of foliar stomata is correlated with plant habit. Rao and Ramayya [31] reported $35.9 \%$ plants as poor epistomatic or functional hypostomatic in the order Malvales. These plants are essentially xeric in habit adapted for conditions of stress. This seems to be true in case of $P$. quadrifida where the leaves are epistomatic and have xerophytic features such as succulent and leathery nature of leaves with thick cuticle. Trichomes in the form of papillae were found in P. quadrifida while $P$. grandiflora and $P$. oleracea were glabrous. Papillate trichomes have also been reported in Talinum [27]which is a member of Portulacaceae.

\section{Conclusion}

The present study revealed that change in geographical region could lead to variations within the species. Differences observed in micromorphological features of Portulaca species found in India are smaller size of stomata, ordinary epidermal cell to be polygonal with sinuous anticlinal walls, and $P$. quadrifida to be epistomatic with isodiametric epidermal cells on the abaxial surface. The species can be distinguished from one another as $P$. oleracea and $P$. grandiflora are amphistomatic while $P$. quadrifida is epistomatic. Micromorphological features revealed that $P$. grandiflora can easily be distinguished from $P$. oleracea as its size of stomata (length and width) and length of epidermal cell are larger as compared to $P$. oleracea. Stomatal index percent and stomatal frequency per $\mathrm{mm}^{2}$ are higher in $P$. quadrifida while $P$. grandiflora has larger stomatal size and length of epidermal cell within the species.

A diagnostic identification key for the three species is prepared as follows:

(1) leaves are epistomatic and pubescent-P. quadrifida,

(1) leaves are amphistomatic and glabrous-2,
(2) mean stomatal size, larger length of epidermal cells, and stomata arranged at a right angle to the midribP. grandiflora,

(2) mean stomatal size, smaller length of epidermal cells, and stomata irregularly scattered with to respect to midrib-P. oleracea.

\section{Acknowledgment}

The authors thank Dr. Manoj Limaye, Associate Professor, Department of Geology, Faculty of Science, The Maharaja Sayajirao University of Baroda, Vadodara, for helping in the photomicrography of the species.

\section{References}

[1] J. M. Neill, "Synopsis of a revised classification of the Portulacaceae," Taxon, vol. 23, no. 5-6, pp. 725-728, 1974.

[2] R. Geesink, "An account of the genus Portulaca in IndoAustralia and the pacific (Portulacaceae)," Blumea, vol. 17, pp. 275-301, 1969.

[3] M. G. Gilbert and S. M. Phillips, "A review of the oppositeleaved species of Portulaca in Africa and Arabia," Kew Bulletin, vol. 55, no. 4, pp. 769-802, 2000.

[4] E. L. D. Seymour, Encyclopaedic Dictionary of Horticulture, vol. 2, Discovery, New Delhi, India, 1997.

[5] Wealth of India: A Dictionary of Indian Raw Materials and Industrial Products. Raw Materials, vol. 8, National Institute of Science Communications CSIR, 1998.

[6] P. Chavalittumrong, B. Sriwanthana, A. Rojanawiwat et al., "Safety of the aqueous extract of Portulaca grandiflora Hook in healthy volunteers Songklanakarin," Journal of Science and Technology, vol. 29, supplement I, pp. 95-100, 2007.

[7] S. K. Mulla and P. Swamy, "Preliminary pharmacognostical and phytochemical evaluation of Portulaca quadrifida Linn," International Journal of PharmTech Research, vol. 2, no. 3, pp. 1699-1702, 2010.

[8] K. R. Kirtikar and B. D. Basu, Indian Medicinal Plants, vol. 2, Dehra Dun, Uttaranchal, India, 2001.

[9] S. Foster and R. Caras, A Field Guide to Venomous Animals and Poisonous Plants of North America (North of Mexico), Houghton Mifflin, Boston, Mass, USA, 1994.

[10] M. Grieve, Modern Herbal: The Medicinal Culinary Cosmetic and Economic Properties, Cultivation and Folklore of Herbs, Grasses, Fungi, Shrubs and Trees with all Their Modern Scientific Uses, Dorset Press, New York, NY, USA, 1992.

[11] D. Ahmed, M. Sharma, A. Mukerjee, P. W. Ramteke, and V. Kumar, "Improved glycemic control, pancreas protective and hepatoprotective effect by traditional poly-herbal formulation, "Qurs Tabasheer" in streptozotocin induced diabetic rats," $B M C$ 
Complementary and Alternative Medicine, vol. 13, article 10, 2013.

[12] N. M. S. Hassan, U. Meve, and S. Liede-Schumann, "Seed coat morphology of Aizoaceae-Sesuvioideae, Gisekiaceae and Molluginaceae and its systematic significance," Botanical Journal of the Linnean Society, vol. 148, no. 2, pp. 189-206, 2005.

[13] V. V. Sivarajan and M. C. Gopinathan, "Seed coat micromorphology of Caryophyllales: observations on some Molluginaceae," Proceedings: Plant Sciences, vol. 94, no. 1, pp. 51-57, 1985.

[14] G. Mostafavi, M. Assadi, T. Nejadsattari, F. Sharifnia, and I. Mehregan, "Seed micromorphological survey of the Minuartia species (Caryophyllaceae) in Iran," Turkish Journal of Botany, vol. 37, pp. 446-454, 2013.

[15] I. Dinter and K. Haas, "Epicuticular wax and anatomical features of Arthraerua leubnitziae (Kuntze) Schinz (Amaranthaceae) related to the ecological conditions in the Namib Desert," Dinteria, no. 30, pp. 1-8, 2008.

[16] S. M. Fank-de-Carvalho, M. R. D. A. Gomes, P. Í. T. Silva, and S. N. Báo, "Leaf surfaces of Gomphrena spp. (Amaranthaceae) from Cerrado biome," Biocell, vol. 34, no. 1, pp. 23-35, 2010.

[17] T. Engel and W. Barthlott, "Micromorphology of epicuticular waxes in Centrosperms," Plant Systematics and Evolution, vol. 161, no. 1-2, pp. 71-85, 1988.

[18] E. Ataşlar, "Morphological and anatomical investigations on the Saponaria kotschyi Boiss. (Caryophyllaceae)," Turkish Journal of Botany, vol. 28, no. 1-2, pp. 193-199, 2004.

[19] S. M. Fank-de-Carvalho and S. N. Bao, "Leaf micromorphology of Gomphrena spp. (Amaranthaceae)," Acta Microscopia, vol. 16, no. 1-2, pp. 238-239, 2007.

[20] T. Agarwal and A. S. Yadav, "Micromorpholgy of the leaf epidermis of Achyranthes aspera L," Journal of Phytological Research, vol. 20, no. 1, pp. 61-66, 2007.

[21] V. H. Heywood, Ed., Flowering Plants of the World, Oxford University Press, Oxford, UK, 1978.

[22] A. B. Kadiri, "Comparative foliar micro-morphological characters of the species of Portulacaceae in Nigeria," Bulletin of Pure \& Applied Sciences-Botany, vol. 25, article 166, 2006.

[23] C. R. Metcalfe and L. Chalk, Anatomy of the Dicotyledons, Clarendon Press, Oxford, UK, 1950.

[24] M. A. Hershkovitz, "Leaf morphology of Calandrinia and Montiopsis (Portulacaceae)," Annals of the Missouri Botanical Garden, vol. 80, no. 2, pp. 366-396, 1993.

[25] A. Baruah and S. C. Nath, "Foliar epidermal characters in twelve species of Cinnamomum schaeffer (Lauraceae) from Northeastern India," Phytomorphology, vol. 47, no. 2, pp. 127134, 1997.

[26] M. A. Hershkovitz, "Leaf morphology of Cistanthe spach (Portulacaceae)," Annals of the Missouri Botanical Garden, vol. 78, pp. 1022-1060, 1991.

[27] J. Swarna and R. Ravindhran, "Pharmacognostical and phytochemical evaluation of Talinum triangulare (Jacq.) Willd," International Journal of Pharmacy \& Pharmaceutical Sciences, vol. 5, supplement 2, pp. 249-256, 2013.

[28] T. Rajagopal, "Distributional pattern and taxonomic importance of foliar stomata," International Journal of Botany, vol. 2, no. 1, pp. 63-69, 1979.

[29] E. J. Salisbury, " On the causes and ecological significance of stomatal frequency with special reference to woodland flora," Philosophical Transactions of the Royal Society, vol. 216, pp. 165, 1927.
[30] J. E. Weaver and F. E. Clements, Plant Ecology, McGraw-Hill, New York, NY, USA, 1936.

[31] S. R. S. Rao and N. Ramayya, "Distribution of stomata and its relation to plant habit in the order Malvales," Indian Journal of Botany, vol. 4, no. 2, pp. 149-156, 1981. 

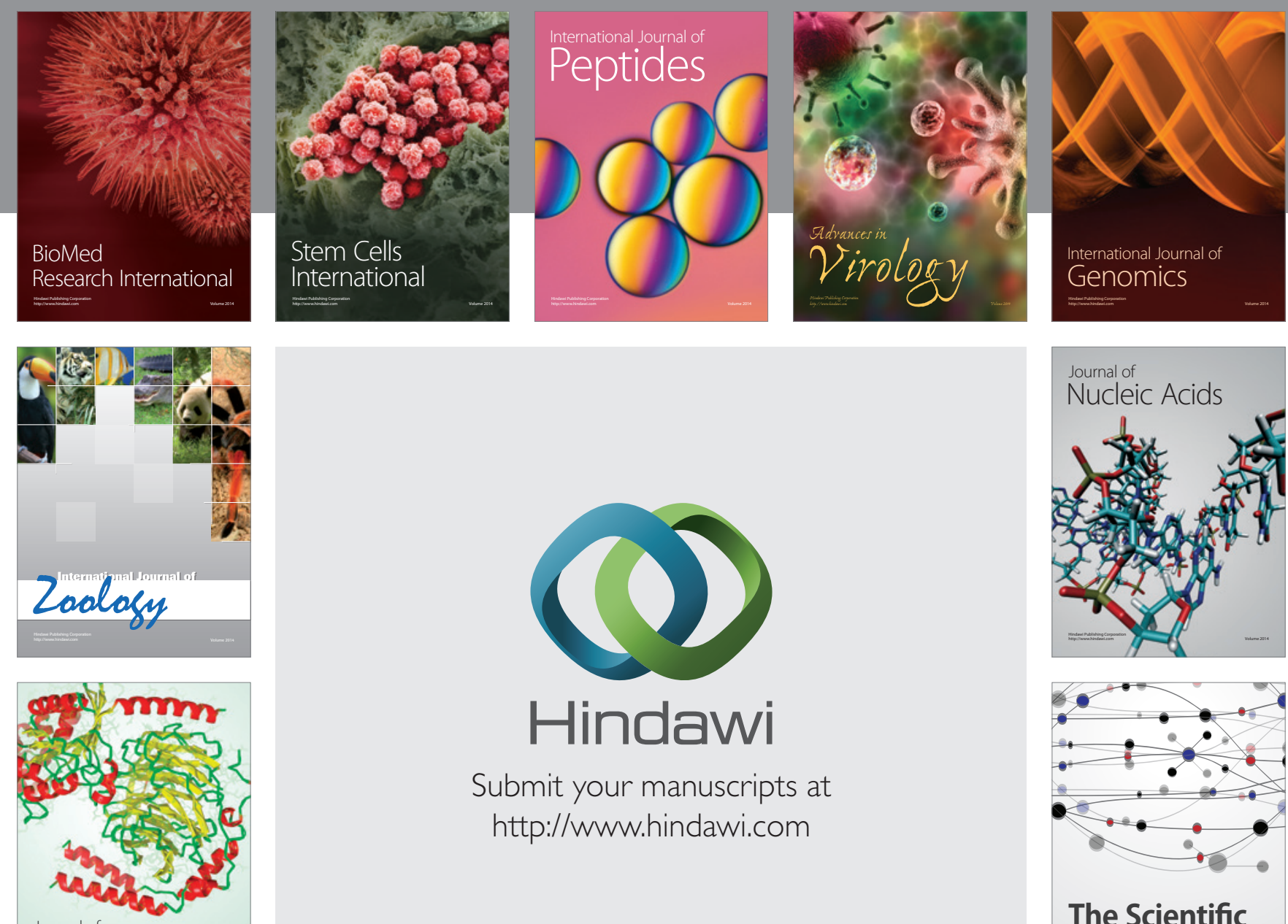

Submit your manuscripts at

http://www.hindawi.com

Journal of
Signal Transduction
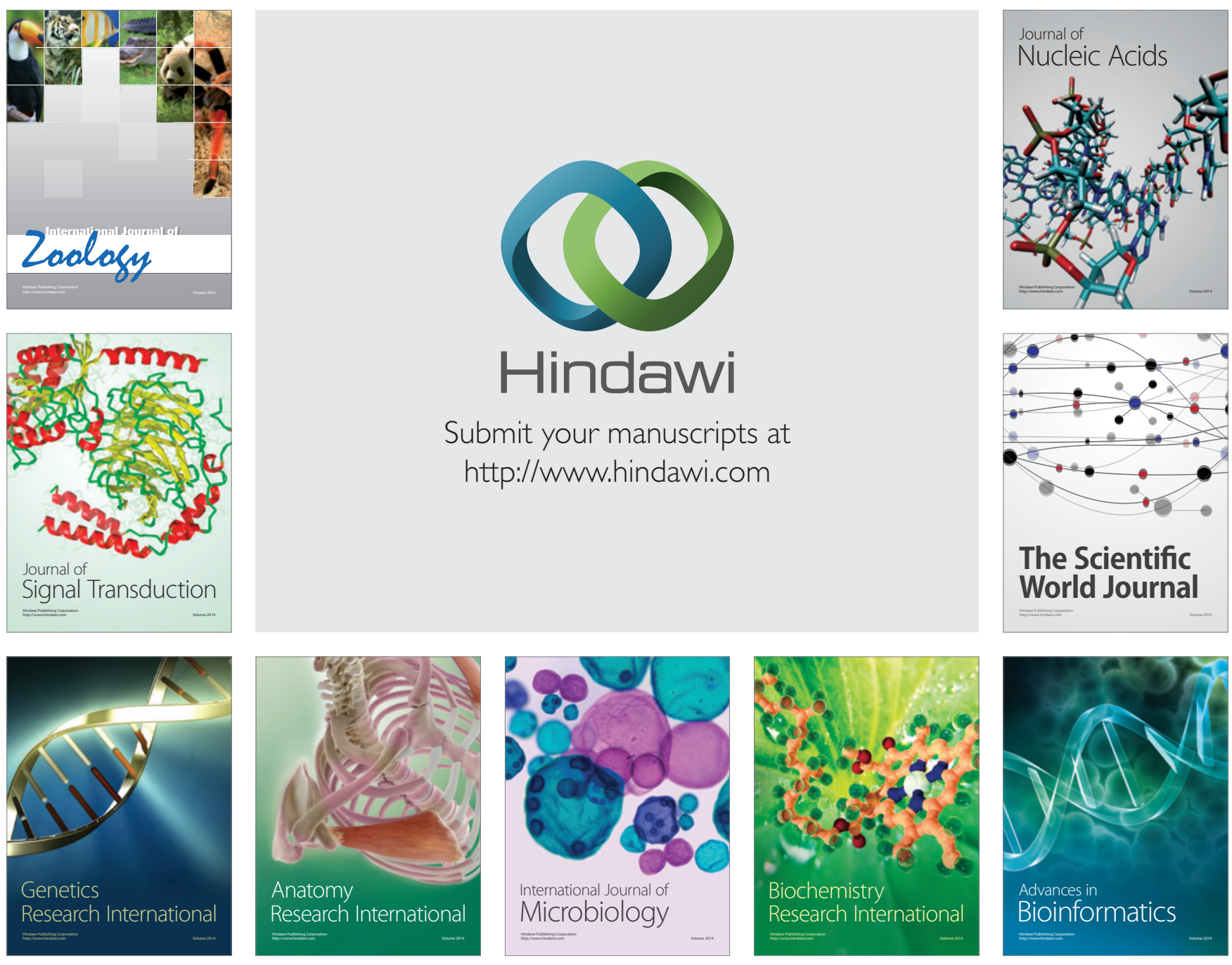

The Scientific World Journal
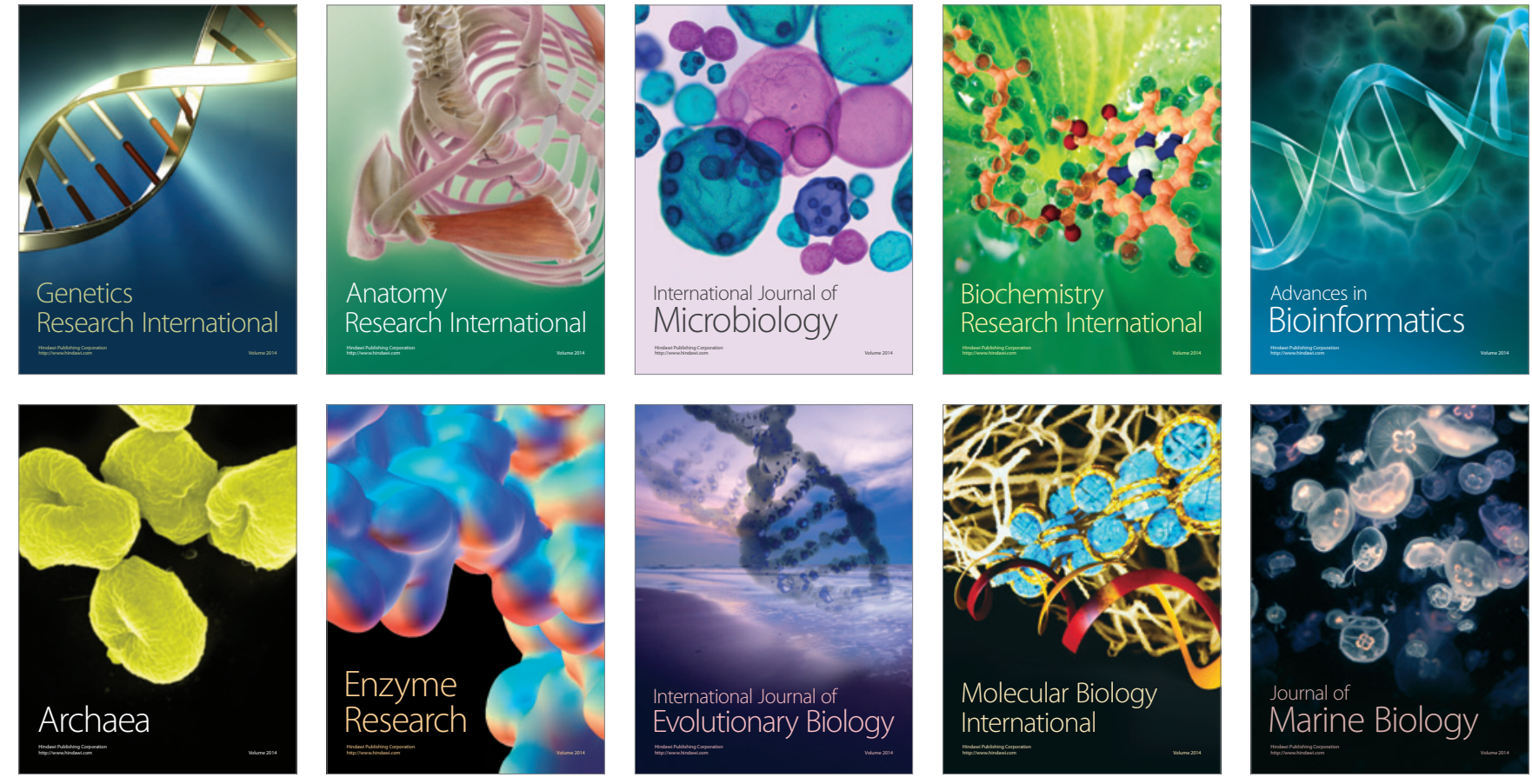